\title{
Advances in the spread of vegetative blueberry
}

\author{
Márcia Wulff Schuch ${ }^{1} \&$ Zeni Fonseca Pinto Tomaz ${ }^{2}$
}

\begin{abstract}
The lack of an efficient method of propagation in some cultivars makes it difficult to expand the blueberry culture. In Brazil, we still do not produce seedlings with needed quality and quantity to improve the sector. The cloning of the selected material through mini propagation and micro propagation is an alternative to increase the multiplication and rooting capacity of the blueberries. Allied to this, the use of cultivation system without soil for the development of cloned material facilitates the seedlings production. In addition, we can keep matrices in small spaces with the use of mini-gardens and clonal micro-gardens controlling climatic and nutritional factors. In the Laboratory of Fruit Plants Propagation, of the Phytotechnology Department of the School of Agronomy Eliseu Maciel of the Federal University of Pelotas we have searching for more than ten years the micro propagation and the mini propagation allied to the clonal gardens kept in a protected place, reducing the physical space and improving phytosanitary control. The experiments carried out brought important information regarding to the vegetative propagation of the blueberry to improve the seedling production process for this species. In this way, researches that have been realized seek to generate knowledge about the best way of propagating and conducting this fruit. Index terms: seedlings, cloning, mini propagation and micro propagation, cultivation system without soil.
\end{abstract}

\section{Avanços na propagação vegetativa de mirtileiro}

Corresponding author: marciaws@ufpel.tche.br

Received: October 03, 2018 Accepted: May 18, 2018

Copyright: All the contents of this journal, except where otherwise noted, is licensed under a Creative Commons Attribution License.

\section{(cc) $\mathbf{E Y}$}

Resumo - A falta de método eficiente de propagação em algumas cultivares dificulta a expansão da cultura do mirtileiro. No Brasil ainda não se produz muda com qualidade e quantidades necessárias para alavancar o setor. A clonagem do material selecionado através de minipropagação e micropropagação é uma alternativa para aumentar a capacidade de multiplicação e enraizamento do mirtileiro. Aliado a isto, o uso dos sistemas de cultivo sem solo, para o desenvolvimento do material clonado, facilita a produção de mudas. Além disso, podemos manter matrizeiros em pequenos espaços com a utilização de minijardins e microjardins clonais, controlando fatores climáticos e nutricionais. No Laboratório de Propagação de Plantas Frutíferas, do Departamento de Fitotecnia da Faculdade de Agronomia Eliseu Maciel da Universidade Federal de Pelotas tem-se buscado pesquisar, há mais de dez anos, a micropropagação e a minipropagação aliado aos jardins clonais mantidos em local protegido, reduzindo o espaço físico e melhorando, principalmente, $o$ controle fitossanitário. Os experimentos realizados trouxeram importantes informações em relação a propagação vegetativa do mirtileiro para a melhoria do processo de produção de mudas para esta espécie. Dessa forma, as pesquisas que estão sendo realizadas buscam gerar conhecimento sobre a melhor forma de propagação e condução dessa frutífera.

Termos para indexação: plântulas, clonagem, mini-propagação e micro-propagação, sistema de cultivo sem solo.

\footnotetext{
${ }^{1}$ Agro Eng. Dr. Professor of the Department of Plant Science, Faculty of Agronomy Eliseu Maciel, Federal University of Pelotas- RS. Brazil. E-mail: marciaws@ufpel.tche.br (ORCID 0000-0001-5237-8302)

${ }^{2}$ Agro Eng. Dr. PNPD Scholarship Program of the Postgraduate Program in Agronomy, Fruit Farming Temperate Weather, FAEM/UFPel. Pelotas- RS. Brazil. E-mail: zfptomaz@yahoo.com.br (ORCID 0000-0003-1152-0936)
} 


\section{Introduction}

The southern region of Brazil has great potential for the production of small fruits, especially blueberry. The species Vaccinium ashei Reade belongs to the "rabbit eye" group that cultivars require 300 to 650 hours of cold and temperatures below $7{ }^{\circ} \mathrm{C}$ and they can be produced in regions that do not have a sum of hours of cold so high. Highbush blueberries (Vaccinium corymbosum) are more demanding in cold than rabbit eye, and more recently introduced cultivars of Southern Highbush Blueberries which are less cold demanding (250 hours) than the traditional highbush (HOFFMANN; ANTUNES , 2017).

This species had its implantation in the 1980 s through a collection of cultivars introduced to Embrapa Temperate Clime (Pelotas, RS) by the researcher Alverides Machado dos Santos and the first commercial initiative in the country began in 1990, in Vacaria, RS (FACHINELLO, 2008).

The lack of efficient propagation method in some cultivars makes it difficult to the crop expansion. In Brazil, there is still no quality and quantities production needed to leverage the sector. Commercially, seedling production limited by a number of factors such as the lack of efficient rejuvenation methods for adult material and appropriate techniques for managing the propagation environment as well as the difficulty in nutrition handling and survival of post-rooting cuttings (TOMAZ, 2014).

The cloning of the selected material through mini propagation and micro propagation is an alternative to increase the multiplication and rooting capacity of blueberry. Allied to this, the use of cultivation system without soil for the development of the cloned material facilitates the production of seedlings. In addition, we can keep blueberry in small spaces with the use of clonal mini gardens and micro gardens controlling climatic and nutritional factors (NASCIMENTO, 2011a).

The seedlings propagated by different methods of asexual propagation such as micro propagation, micro cutting and mini cutting have their completion until the complete development in non-soil cultivation systems (SCHUCH, PEIL, 2012). Some experiments are already in the final evaluation stage with the seedlings taken to the field constituting an orchard for the validation of the entire production process.

In the Laboratory of Fruit Plants Propagation of the Department of Phytotechnology in the School of Agronomy Eliseu Maciel of the Federal University of Pelotas, we have search for more than ten years the micro propagation and mini propagation allied to the clonal gardens kept in a protected place, reducing the physical space and improving phytosanitary control.

Tissue culture is a technique that successfully provides the mass propagation of fruit and which has used with efficient results for the production of healthy seedlings with high quality. Although micro propagation is widely use and presents advantages over traditional propagation method, its commercial use in seedling production is limited, mainly due to the high cost of obtaining the seedlings and the difficulty of some genotypes to adapt to this type of propagation (ERIG, SCHUCH, 2005).

In the case of blueberry, the most critical phase is the in vitro establishment of the propagated material. Researches make possible to determine the best methodology for in vitro establishment of the genotypes.

After we studied in vitro and ex vitro multiplication and rooting phases. At the time of obtaining the micro propagated material, to optimize the process experiments were made with systems of cultivation without soil with the objective of observing the growth of the seedling as well as the maintenance of clonal micro gardens.

Protocols for the in vitro establishment of blueberry (Vaccinium ashei Reade) were developed in order to optimize the production of micro propagated seedlings of this species (Figure 1). First, it was necessary to define the maintenance place of the explant donor plants and the concentration of the disinfectant solution. In the sequence, it was evaluated the behavior of these plants under the presence and absence of light as well as the asepsis process. Then, we tested different cultivars, the type of explant donor branch and the cytokine that favors the in vitro establishment of blueberry (SILVA et al., 2006). At the end of the research, we tested different cultivars, the type of explant donor branch and the cytokine that favors in vitro establishment of blueberry (SILVA et al., 2008).

The cultivar Bluebelle was the one with the lowest establishment index due to high bacterial contamination and explants oxidation; however, survival and establishment were not affected by the location of the explants and by the concentration of sodium hypochlorite used in the disinfestation. It was also observed that the cultivar Florida was not affect by the prewash of the shoots, however it was possible to maintain the matrices plants in the dark for 15 days. For in vitro establishment of 'Delite' explants the culture medium favoring the in vitro establishment is WPM plus cytokine zeatin, which, in addition to providing survival and establishment of explants reduces oxidation of them. In in vitro establishment of Vaccinium ashei Reade, cold is a treatment that can apply to the herbaceous branches of explant donors (SILVA et al., 2006); and the use of AIA growth regulator in the culture medium reduces the oxidation of them. Among the tested cultivars, Delite and Woodard showed greater easiness in the establishment, whereas 'Bluebelle' showed the greatest difficulty in establishing (SILVA et al., 2008). In general, the WPM medium added with Zeatine in the first stage, later replaced by $2 \mathrm{ip}$ is indicated for in vitro establishment of blueberry. 


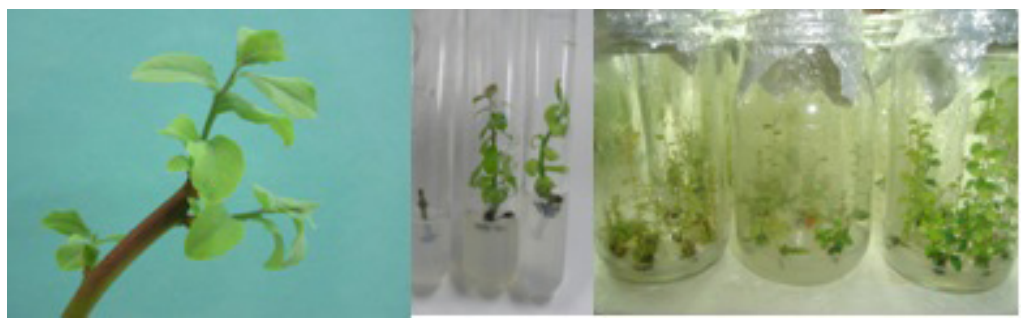

Figure 1. Source of explants for micro propagation, established blueberry and in vitro multiplication material. Photo: Silva, L. C.

On the other hand, as mentioned earlier to the application of micro propagation in fruit growing become commercially viable and can compete with traditional propagation methods such as cuttings it is necessary to reduce the production cost.

For this, the development of photoautotrophic micro propagation systems (production of micropropagules without addition of sucrose in the culture medium and under environmental conditions that promote photosynthesis in the plant) with the use of natural light appears as a possibility with the potential to increase the efficiency of micro propagation and help reduce their cost. Thus, studies were carried out with photoautotrophic multiplication of blueberry (DAMIANI et al., 2008). First, it was necessary to define the constitution of the culture medium that provided the best results, both in the multiplication as in vitro rooting of blueberry under conventional micro propagation conditions. From this, photoautotrophic micro propagation studies were realized on the use of natural and artificial light, under the constitution of the culture medium (different concentrations of sucrose) and types of sealing. The growth place does not interfere with the in vitro multiplication of blueberry when the explants are cultured in the absence or at low concentrations of sucrose (15 g.L $\left.\mathrm{L}^{-1}\right)$ (DAMIANI et al., 2008). The photoautotrophic rooting of blueberry by means of cultivation in free sucrose medium increases the rooting percentage and the number of roots, and when associated the bottle sealing with cotton, it promotes the increase of the root length and the total fresh mass. During the summer, the highest rooting percentages are obtained and this can be done successfully in greenhouse (DAMIANI et al., 2009).
Promising results for photoautotrophic micro propagation with the use of natural light have great potential to help reduce the production costs of micro propagated seedlings, directly, through the reduction of energy expenditure, and indirectly, improving the quality of the seedlings, reducing loss of plants during acclimatization and reducing microbial contamination (DAMIANI et al., 2009).

There were also carried out studies aiming addressing various aspects related to blueberry spread (Vaccinium spp) (Figure 2). Among them were tested the ex vitro rooting of blueberry cultivars (Bluebelle, Woodard and Georgiagem) in the substrates Plantmax ${ }^{\circledR}$; Plantmax $^{\circledR}+$ Sawdust $(1: 1)$; Sawdust; Plantmax ${ }^{\circledR}+$ vermiculite (1:1) and vermiculite (PELIZZA et al., 2012). The process of acclimatization and growth of micro propagated plants of blueberry 'Climax' cultivar was approached in different substrates (carbonized rice hulls + Fertile $^{\circledR}$ Humus, Plantmax ${ }^{\circledR}+$ Vermiculite and soil + Young pines sawdust) with the use of two cover systems (with and without plastic cover on the plants) evaluated over 210 days (PELIZZA, 2009). In the micro cutting process of blueberry 'Climax' were compared substrates (Plantmax $^{\circledR}+$ carbonizes rice husk (1: 1), Hummus Fertile $^{\circledR}$ and Vermicomposting Bovine) and two portions of the branch (medium and apical) (PELIZZA et al., 2012). The use of phytorregulators - benzyl aminopurine (BAP) and gibberellin $\left(\mathrm{GA}_{3}\right)$ - in different concentrations (control without regulators, $250 \mathrm{mg} / \mathrm{L}^{-1}$ of BAP, $250 \mathrm{mg} \mathrm{L}^{-1}$ of $\mathrm{BAP}+250 \mathrm{mg} \mathrm{L}^{-1}$ of $\mathrm{GA}_{3}$ ) on growing of ' $\mathrm{O}$ ' Neal' micro cuttings in five different period of time $(0,30,60,90$ and 120 days) (PELIZZA et al., 2010b). Next we studied the growth of 'Georgiagem' blueberry micro propagated plants with different concentrations of $\mathrm{GA}_{3}(0,50,100$ and $\left.150 \mathrm{mg} \mathrm{L}^{-1}\right)$ as a function of time (0,30 and 60 days $)$ (PELIZZA et al. Al., 2010a).

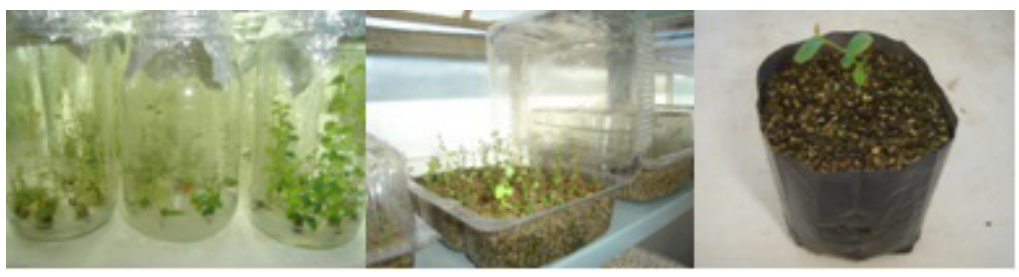

Figure 2. Ex vitro blueberry rooting. Photo: Pelizza, T. R. 
The substrates for ex vitro rooting of blueberry explants were vermiculite and tanned sawdust. Among the cultivars, Bluebelle and Woodard presented significant results (PELIZZA et al., 2012). The substratum and cover system indicated for the acclimatization and growth of blueberry plants 'Climax' are Plantmax ${ }^{\circledR}+$ vermiculite without plastic cover (PELIZZA, 2009). Medium micro cuttings provide satisfactory results for the rooting of blueberry 'Climax'. The combination of Plantmax ${ }^{\circledR}+$ carbonized rice husk is the substrate indicated for the rooting of blueberry micro cuttings (PELIZZA et al., 2012) (Figure 3). Blueberry plants 'Georgiagem' respond positively to the action of gibberellin being it mainly on the aerial part of the plant (PELIZZA et al., 2010b). The concentration of $50 \mathrm{mg} \mathrm{L}^{-1}$ of $\mathrm{GA}_{3}$ is enough to obtain response of blueberry plants as to their growth (PELIZZA et al., 2010a).

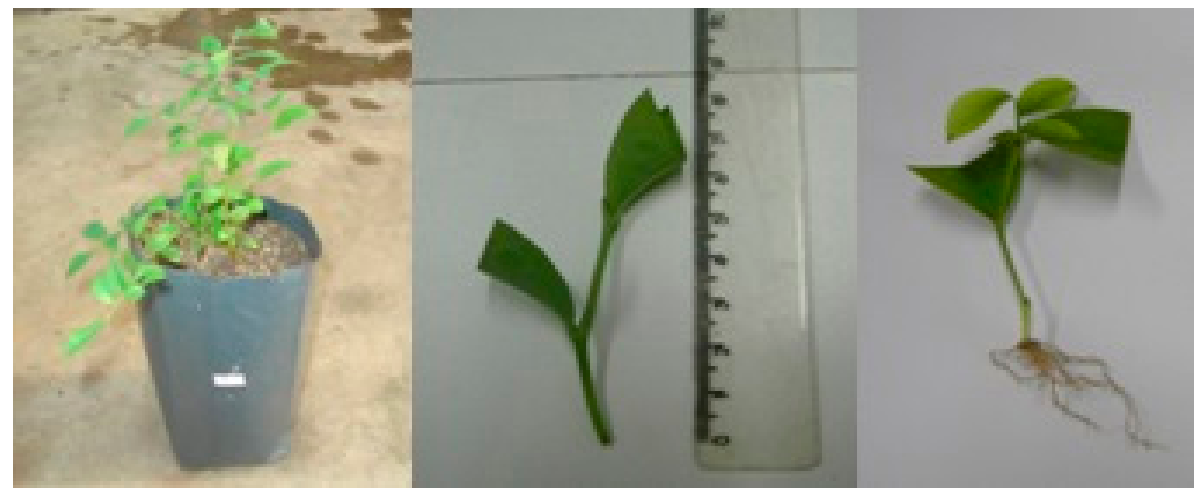

Figure 3. Micro cutting in blueberry. Photo: Pelizza, T. R.

The influence of arbuscular mycorrhizal fungi (AMF) in the production of micro propagated seedlings of blueberry cultivars Bluegem and Woodard (FARIAS et al., 2014) were evaluated, preceded by the tests of how to isolate and identify these fungi from the orchards in Southern region - RS (FARIAS, 2012). Soil and root samples have been collected in commercial and experimental blueberry orchards from the municipalities of Pelotas, Morro Redondo, and Jaguarão and used ecological indices as the way to evaluate the populations in the orchards under study and the analysis of main components to evaluate the physical and chemical attributes of the soil in relation to the AMFs. We identified eighteen different AMF spore morph types. The percentages of AMF root colonization were high, varying from 40 to $80 \%$. The cultivars located in the commercial orchard of the municipality of Morro Redondo were the most colonized in relation to the others. The highest number of found spores was in the cultivar O'Neal in the commercial orchard of Micaela. The relative abundance and the highest rates of Shannon (H') diversity and richness $(\mathrm{R})$ were found in the oldest areas of cultivation, the experimental old orchard of Embrapa (EPV) and the commercial orchard of Morro Redondo (MR). The relative frequency demonstrates the prevalence of species of the genus Glomus and Acaulospora in all orchards. The dominance evaluated by the Simpsom index (Is) presented the same trend of Shannon diversity and richness. Among the soil chemical parameter, there were high correlation of AMF species with $\mathrm{pH}$, volume (\%), phosphorus and sand variables (FARIAS, 2012). The AMFs isolates for the production of seedlings were provided by the species bank of the Horticulture and Forestry Department of UFRGS (FARIAS et al., 2014). Four species of AMFs (Glomus clarum, Glomus etunicatum and Scutellospora heterogama and Gigaspora margarita) were tested on the seedlings production of cultivars Woodard and Bluegem. The AMFs provided positive effect on seedling production, especially Gigaspora margarita, which provided better nutrition and increased biomass growth in cultivar Woodard and the Glomus etunicatum for the cultivar Bluegem. The efficiency of the AMFs symbiosis in blueberry cultivars depends on the specific AMF $\mathrm{x}$ host interaction.

It was also studied the production of blueberry seedlings in different farming systems conducted in an agricultural greenhouse (Figure 4). First evaluated the growth and nutrient content of blueberry micro propagated seedlings for the formation of clonal micro garden in conventional and soil - free systems, irrigated with nutrient solution. Seedlings of cultivars Bluebelle and Woodard with three months of acclimatization were submitted to two cultivation systems: in conventional system they were kept in polyethylene bags containing Plantmax ${ }^{\circledR}$ + vermiculite (1: 1) and irrigated with nutrient solution every 15 days; and soil-free system in which they remained in plastic flowerpots containing sand, irrigated with nutritive solution daily. We evaluated the shoot height; number of shoots and average length of shoots monthly, and at 90 days fresh shoot mass, fresh and dry root mass and nutritional analysis of leaves. The soil-free system provided better results for all variables evaluated in both cultivars. The seedlings cultivated in the soil-free system presented higher nutrient contents suitable for this crop (NASCIMENTO et al., 2011b). 


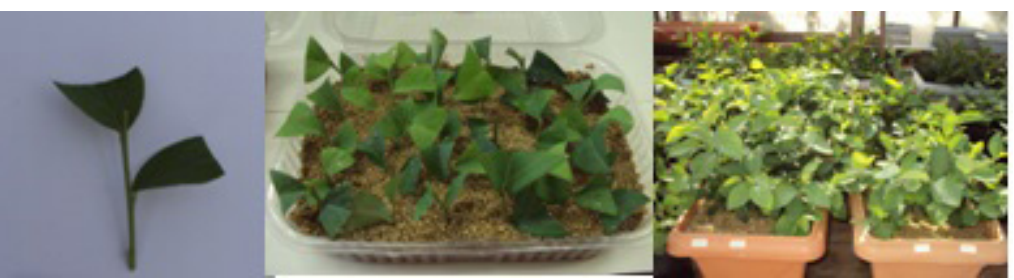

Figure 4. Clonal Blueberry micro garden. Photo: Nascimento, D.

In another experiment, we verified the yield and rooting of the micro shoot on Bluebelle and Woodard cultivars from two culture systems, conventional and soil-free using different concentrations of IBA (indole butyric acid) (Figure 5). The use of hydroponic clonal micro gardens has reported successfully for forest species and may become an excellent alternative for fruit species, such as blueberry. The blueberry rooting micro cuttings belonging from two cropping systems submitted to different concentrations of IBA $(0,500,1,000,1,500$ and 2,000 mg. $\left.\mathrm{L}^{-1}\right)$, packed in plastic boxes containing vermiculite, and at 90 days of cultivation it was evaluated their yield. Percentages of survival and rooting, the length of the largest root, the number and the average length of the shoots, the number of leaves and the fresh and dry root masses were evaluated. The soil-free system provided a yield of micro cuttings significantly higher than the conventional one; however, this material had lower percentages of survival and rooting. All treatments, including those without IBA presented rooting percentages above 50\% (NASCIMENTO et al., 2011a).

Growth and yield were also evaluated in micro propagation of micro cuttings seedlings of blueberry Bluebelle, Bluegem, Georgiagem and Delite cultivars in NFT (Nutrient Film Technique) hydroponics system (Figure 5). In general, all cultivars presented a gradual increase of growth according to the cultivation time however, the cultivar Bluegem presented better results (SCHUCH et al., 2012).

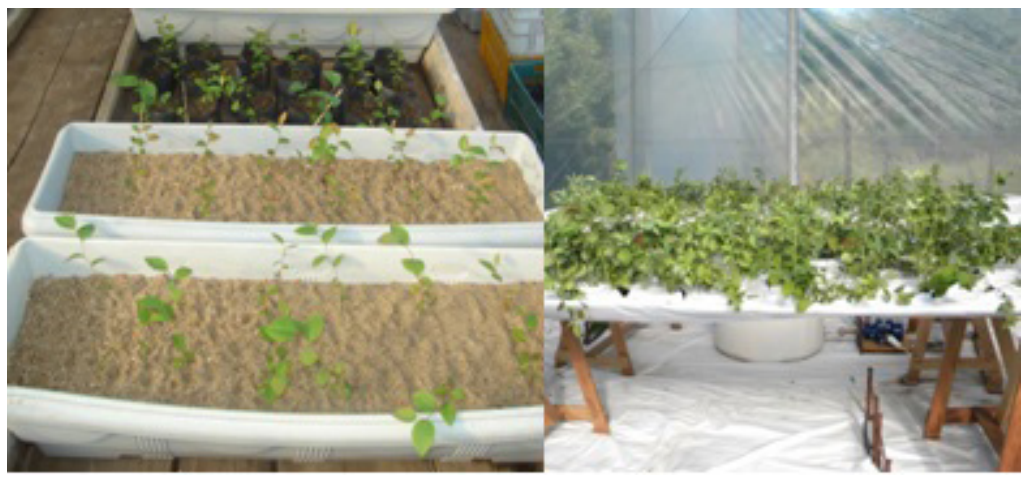

Figure 5. Soil-free cultivation systems and NFT. Photo: Nascimento, D.

In order to produce blueberry seedlings of good quality at reduced price and in large quantity, it is necessary to develop efficient systems for the cultivation of seedlings, in order to optimize the time space and phytosanitary guarantees. We studied formation of blueberry clonal micro gardens in soil-free cultivation systems under greenhouse condition on the survival and microbial production of micro propagated blueberry of cultivars Aliceblue and Woodard, belonging to the Rabbit eye group, on soil-free system (vase with sand substrate and daily supply of nutrient solution) and with organic mineral substrate (plastic bags with commercial substrate and nutrient supply solution, every 15 days). During the experiment, there were successive collections with intervals of two months, totaling 11 collections during the period from September 2011 to 2013. It observed that the soil-free system was superior to the organic mineral substrate for the micro cuttings production on both cultivars. The highest productivity of micro cutting occurred with the Aliceblue cultivar in a soil-free system, with 237.67 micro cuttings per master plant at the end of two years. However, in this condition, there was less survival of the matrix plants. The production of micro cuttings presents alternation, varying according to the collection time. The survival of the matrix plants decreased after successive collections, occurring higher mortality after the summer collections. Parallel to this study, there was the evaluation of micro cuttings rooting collected at different times, evaluating the percentage of survival and rooting. It observed that higher and lower survival rates cyclically alternate between collections, with a tendency to repeat each year. The system of organic mineral substrate cultivation presents higher percentage of survival and rooting of the micro cutting in some collections when 
compared to soil-free system. The highest percentage of rooting in the two cropping systems was in January collection, being the summer the best time for collection and rooting of blueberry micro cutting. The Woodard cultivar presented percentage of rooting superior to Aliceblue in only three collections (AFFONSO, 2014).

It was studied two nutrient solutions developed for the irrigation plants cultivated in blueberry clonal micro-garden in a soil-free system being " $\mathrm{A}$ " solution used in the previous experiments and with electrical conductivity (EC) of $1.3 \mathrm{dS} \mathrm{m}^{-1}$, and "B" solution, new nutrient solution with $\mathrm{EC}$ of $2.3 \mathrm{dS} \mathrm{m}^{-1}$. We used in this research the cultivars Woodard and Bluegem belonging to the group Rabbit eye during a period of 180 days with evaluations every 30 days. At the end of the experiment, plants of both cultivars presented higher survival when irrigated with A solution (Table 1). The cultivar Bluegem was more tolerant to salinity than the Woodard cultivar when irrigated with B solution (Table 1). Thus, the nutrient A solution is the most recommended for the cultivation of micro propagated blueberry plants in a soil-free system, providing a greater survival, growth and development of the plants. The nutrients $\mathrm{N}, \mathrm{P}, \mathrm{Mg}, \mathrm{Mn}, \mathrm{Zn}$ and Fe have been found in the matrix plants on similar concentrations to those considered adequate in the adult plants tissue. Already, $\mathrm{K}$ is in higher concentration and $\mathrm{Ca}$, and $\mathrm{Cu}$ in lower concentration than those considered suitable for adult plants (AFFONSO, 2014).

Table 1. Concentration of nutrient ions, electrical conductivity and $\mathrm{pH}$ of nutrient solutions $\mathrm{A}$ and $\mathrm{B}$ developed for the blueberry culture and used in a clonal semi-hydroponic garden.

\begin{tabular}{|c|c|c|}
\hline \multicolumn{3}{|c|}{ Nutrition Solution } \\
\hline & $\mathrm{A}^{1}$ & $\mathrm{~B}^{2}$ \\
\hline Macronutrients & & $\mathrm{mmol} \mathrm{L}^{-1}$ \\
\hline NO3- & 5.1 & 13.2 \\
\hline H2PO4 - & 1.1 & 1.0 \\
\hline SO42- & 3.7 & 4.4 \\
\hline NH4+ & 3.8 & 8.0 \\
\hline $\mathrm{K}+$ & 3.0 & 5.0 \\
\hline $\mathrm{Ca} 2+$ & 2.3 & 3.0 \\
\hline $\mathrm{Mg} 2+$ & 1.1 & 2.0 \\
\hline Micronutrients & & $\mathrm{mg} \mathrm{L}^{-1}$ \\
\hline $\mathrm{Fe}$ & 1.4 & 3.3 \\
\hline $\mathrm{Mn}$ & 0.6 & 0.6 \\
\hline $\mathrm{Zn}$ & 0.3 & 0.3 \\
\hline $\mathrm{Cu}$ & 0.1 & 0.1 \\
\hline Bo & 0.05 & 0.05 \\
\hline Mo & 0.07 & 0.07 \\
\hline Electric conductivity & $1.3 \mathrm{dS} \mathrm{m}^{-1}$ & $2.3 \mathrm{dS} \mathrm{m}^{-1}$ \\
\hline $\mathrm{pH}$ & $5.0-5.5$ & $5.0-5.5$ \\
\hline
\end{tabular}

${ }^{1}$ Schuch; Peil (2012)

${ }^{2}$ Calculated on the basis of mineral nutrient contents of blueberry seedlings

Studies on the management of the blueberry orchard in Brazil and its field characteristics are still recent. In an attempt to provide information that is more accurate to the producers of this crop, experiments have been conducted in a region with productive potential. In a didactic orchard belonging to Federal University of Pelotas we conducted an experiment with the purpose of observing on the field, blueberries propagated by two different techniques, evaluating vegetative, productive and fruit quality aspects, in order to verify the effect of the rejuvenation obtained through the technique of micro-propagation. For this purpose, we planted one-year-old seedlings of the Bluegem, Briteblue and Woodard cultivars, propagated in vitro and by semi- woody cuttings. We verified that micro propagated plants present, in the field, superior initial vegetative growth, besides productivity and fruit quality similar to the plants propagated by cutting (SOUZA et al., 2011).

It was observed three different cultivars, Briteblue, Woodard and Bluegem, from two propagation (micro propagation and cutting) and different intensities of pruning (control, light and drastic). We verified that plants of the three cultivars propagated through in vitro cultivation presented higher vegetative growth when compared to plants derived from shoots. Drastic pruning provides the development of longer vegetative branches. The micro propagated plants of the cultivar Bluegem produced fruits with higher content of anthocyanins, 
whereas, fruits of Briteblue presented higher levels of these compounds in plants derived from cutting. Finally, fruits harvested in plants without pruning or with light pruning presented higher antioxidant activity, independent of the studied cultivar (SOUZA et al., 2014).

The experiments carried out brought important information regarding the vegetative propagation of blueberry to improve the seedling production process for this species.

\section{Final considerations}

Nowadays, the Propagation of Fruit Plants Laboratory of the Federal University of Pelotas, gives continuity to the developed study, maintaining the blueberry clonal micro garden and conducting evaluations regarding the productivity of mini strains during successive collections, on cultivation system soil free and in packaging and evaluates the rooting of collected mini cuttings at different times of the year. In the micro propagation, new experiments were installed regarding the genetic diversity among subcultures in vitro for this culture. Thus, the researches that have been carried out seek to generate knowledge about the best way of propagating and conducting this fruit plant.

\section{Acknowledgement}

To Coordination for the Improvement of Higher Personnel Education (CAPES) for scholarship granting.

To the Foundation for Research Support of the State of Rio Grande do Sul (FAPERGS) and National Research Council (CNPq), for financial support.

\section{References}

AFFONSO, L.B. Microjardim clonal de mirtileiro em sistemas de cultivo sem solo. Tese (Doutorado Programa de Pós-Graduação em Sistemas de Produção Agrícola Familiar)- Faculdade de Agronomia Eliseu Maciel, Universidade Federal de Pelotas, Pelotas, 2014.

DAMIANI, C.R.; SCHUCH, M.W. Enraizamento in vitro de mirtilo em condições fotoautotróficas. Ciência Rural, Santa Maria, v.39, n.4, p.1012-1017, 2009.

DAMIANI, C.R.; SCHUCH, M.W. Multiplicação fotoautotrófica de mirtilo através do uso de luz natural. Revista Brasileira de Fruticultura, Jaboticabal, v.30, n.2, p.482-487, 2008.
ERIG, A.C.; SCHUCH, M.W. Micropropagação fotoautotrófica e uso da luz natural. Ciência Rural, Santa Maria, v.35, n.4, p.961-965, 2005.

FACHINELLO, J.C. Mirtilo. Revista Brasileira de Fruticultura, Jaboticabal, v.30 n.2, p.285-289, 2008.

FARIAS, D. da H.; PINTO, M.A.B.; CARRA, B.; SCHUCH, M.W.; SOUZA, P.V.D.de. Desenvolvimento de mudas de mirtileiro inoculadas com fungos micorrízicos arbusculares. Revista Brasileira de Fruticultura, Jaboticabal, v.36, n,3, p.655-663, 2014.

FARIAS, D.da H. Utilização de fungos micorrizicos arbusculares na produção de mudas micropropagadas de mirtileiro cv. Bluegem e Woodard. 2012. Dissertação (Mestrado Programa de Pós-Graduação em Agronomia)Faculdade de Agronomia Eliseu Maciel, Universidade Federal de Pelotas, Pelotas, 2012.

HOFFMANN, A.; ANTUNES, L.E.C. Grande potencial. 2017. Disponível em: <http://www.cnpuv.embrapa.br/ publica/artigos/como_cultivar_mirtilo.pdf 2017>.

NASCIMENTO, D.C.; SCHUCH, M.W.; PEIL, R.M.N. Enraizamento de microestacas de mirtileiro provenientes de microjardim clonal semi-hidropônico. Revista Brasileira de Fruticultura, Jaboticabal, v.33, n.4, p.12511256, 2011a.

NASCIMENTO, D.C.; SCHUCH, M.W.; PEIL, R.M.N. Crescimento e conteúdo de nutrientes minerais em mudas de mirtileiro em sistema convencional e semi-hidropônico. Revista Brasileira de Fruticultura, Jaboticabal, v.33, n.4, p.1155-1161, 2011b.

PELIZZA, T.R.; NASCIMENTO, D.C.; AFFONSO, L.B.; CAMARGO, S.S.; CARRA, B.; SCHUCH, M.W. Enraizamento de plântulas de mirtileiro em condição $e x$ vitro com diferentes substratos. Revista Brasileira de Fruticultura, Jaboticabal, v.34, n.1, p.255-261, 2012.

PELIZZA, T.R.; SCHUCH, M.W.; CARVALHO, G.L. Growth of micropropagated blueberry under different GA3 concentrations. Acta Horticulturae, The Hague, v.2, p.617-621, 2010a.

PELIZZA, T.R.; SCHUCH, M.W.; CARVALHO, G.L. Growth evaluation of blueberry minicuttings under different growth regulators.A cta Horticulturae, The Hague, v.2, p.623-628, 2010 b. 
PELIZZA, T.R. Propagação do mirtileiro. Tese (Doutorado Programa de Pós-Graduação em Agronomia)Faculdade de Agronomia Eliseu Maciel, Universidade Federal de Pelotas, Pelotas, 2009.

SCHUCH, M.W.; PEIL, R.M.N. Soilless cultivation systems: a new approach in fruit plants propagation in southern Brazil. Acta Horticulturae, The Hague, v.952, p.877-884, 2012.

SCHUCH, M.W.; PEIL, R.M.N.; NASCIMENTO, D.C. Growth of blueberry cultivars in nft hydroponic system. Acta Horticulturae, The Hague, v.952, p.871-876, 2012.

SILVA, L.C. da; SCHUCH, M.W.; SOUZA, J.A. de; ERIG, A.C.; ANTUNES, L.E.C. Tipo de ramo e efeito do ácido indol acético (AIA) no estabelecimento in vitro de três cultivares de mirtilo. Ciência Rural, Santa Maria, v.38, p.522-525, 2008.
SILVA, L.C.da; SCHUCH, M.W.; SOUZA, J.A.de ; ERIG, A.C.; ANTUNES, L.E.C. Meio nutritivo, reguladores de crescimento e frio no estabelecimento in vitro de mirtilo (Vaccinium ashei reade) cv.Delite. Revista Brasileira de Agrociência, Pelotas, v.12, p.405-408, 2006.

SOUZA, A.L.K.de; PEREIRA, R.R.; CAMARGO, S.S.; FISHER, D.L.de O.; SCHUCH, M.W.; PASA, M.da S.; SCHMITZ, J.D. Produção o e qualidade de frutos de mirtileiros sob diferentes intensidades de poda. Ciência Rural, Santa Maria, v.44, p.2157-2163, 2014.

SOUZA, A.L.K.de; SCHUCH, M.W.; ANTUNES, L.E.C.; SCHMITZ, J.D.; PASA, M.da S.; CAMARGO, S.S.; CARRA, B. Desempenho de mudas de mirtilo obtidas por micropropagação ou estaquia. Pesquisa Agropecuária Brasileira, Brasília, DF,v.46, p.868-874, 2011.

TOMAZ, Z.F.P.; SCHUCH, M.W.; PEIL, R.M.N.; TIMM, C.R.F. Desenvolvimento de porta-enxertos de pessegueiro obtidos de miniestacas, em duas épocas, e sistema de cultivo sem solo. Revista Brasileira de Fruticultura, Jaboticabal, v.36, n.4, p.984-991, 2014. 